\title{
Native American lands and the keystone pipeline expansion: a legal analysis
}

\begin{abstract}
Multiple branches of the U.S. government are involved in a historic legal and political battle over granting permits to a foreign corporation to expand the Keystone Pipeline. The pipeline is designed to carry tar sands oil mined in Canada across the U.S. border to refineries in the southern U.S. The planned pipeline expansion would traverse Native American lands. These lands are protected by treaties signed between the U.S. and the Great Sioux Nation. The Sioux claim that the permits that the developer of the pipeline, TransCanada, a foreign corporation, are seeking to build are being considered by the U.S. government without proper notice or permission from the Tribal Counsel in violation of the Treaties. The Native Americans have declared that if the U.S. grants the permits, it would be considered an act of war. In this evolving article, we will cover important legal issues as well as offer advice and commentary regarding Native American Lands specifically as involves the controversy surrounding the Keystone Pipeline expansion. We trust that it will shed important light on significant issues affecting all Americans and be of aid in practice and life.
\end{abstract}

Volume 6 Issue I - 2018

\author{
Robert Diotalevi, Susan Burhoe \\ Florida Gulf Coast University in Fort Myers, USA
}

Correspondence: Robert Diotalevi, Professor of Legal Studies at Florida Gulf Coast University in Fort Myers, I050 I FGCU Blvd. South Fort Myers, 33965-6565,Florida, USA, Tel 239-590-78I7, Email bobdiotalevi@hotmail.com

Received: May 12, 2017 | Published: January 22, 2018

\section{Introduction}

The recognition by the United States government of Native American sovereignty, the tribal way of life, sacred lands, and access to these lands and precious resources found on these lands is an ongoing struggle between the Government and Native Americans. ${ }^{1}$ Historic political and legal battles involving access through a Native American land continues to leave a mark upon American history. The Keystone Pipeline extension exemplifies this struggle. The current pipeline is one of the pipelines through which crude oil is transported from Canada into the U.S. The 1,179-pipeline extension was projected to move 830,000 barrels of sands oil per day, and is at the center of this battle over land rights of private U.S. citizens, Native Americans, and the U.S. government in its role as guardian of the public interest. Operated by a foreign corporation based in Canada, TransCanada is proposing a modification to their current pipeline that travels from the oil fields of Canada to the Gulf Coast in Texas. TransCanada applied for a permit to expand their privately-owned pipeline system further into the U.S. That application has run into intense opposition from environmental groups that claim that environmental concerns surrounding the pipeline have the potential for a high risk of water pollution from leaks, forest destruction by accessing the tar sand, and significant harm to the indigenous populations. ${ }^{2}$ The current system passes from Alberta, Canada to Texas.

The projected pipeline would carry Canadian oil that comes from processed tar sands through a shorter route from Alberta to Steele City, Nebraska. Objections raised question whether allowing the pipeline's expansion is in the public's best interest. TransCanada and supporters of the project argue that 'the pipeline is a critical infrastructure project for the energy security of the United State and for strengthening the American economy'. ${ }^{3}$ The Governor, a supporter of the pipeline,

${ }^{1}$ Bredhoff, Stacey, American Originals, Seattle: The University of Washington Press, 2001, p.56-57

${ }^{2}$ http://www. foe.org/projects/climate-and-energy/tar-sands/keystone-xlpipeline, Na. Nov.20, 2014

${ }^{3}$ http:// keystone-xl.com/about/ jobs-economic-benefits, Na., Dec. 1, 2014 signed a permit, which provided TransCanada access in Nebraska. ${ }^{4}$ In opposition, three private owners of large tracts of land in Nebraska mounted a legal challenge against the Governor's taking of their land by eminent domain for the pipeline. ${ }^{5}$ The landowners sued saying that the neither the Governor nor Nebraska legislature has this power. While the Nebraska Supreme Court ultimately ruled against the supporters of the pipeline, the ruling did not provide a resolve to the Keystone XL Pipeline issue. ${ }^{6}$ At the federal level, Native American tribes living in these areas protest the pipeline expansion. They argue that the proposed pipeline passes through the Great Sioux Nation lands, which are protected under the Treaties of Fort Laramie $1851 \& 1868 .^{7}$ The Treaties grant the lands to the people of the tribe. According to the Treaties, no outside entity can use the land without the consent of the tribe. The Sioux Nation believes that these legal rights are ignored and calls for justice are silenced. ${ }^{8}$ Recognition of Native American sovereignty is at the heart of the issue. ${ }^{9}$ As original owners of this land, The Sioux claim standing in all matters regarding these lands. They claim that if the U.S. government permits the pipeline they will block all access and the tribes will consider this action to be an 'act of war against their people'. ${ }^{10}$

\section{An historical analysis: pacts, policies and pipeline expansion}

In the late $19^{\text {th }}$ century, "under increasing pressure from American citizens to open more roads to destinations in the West...to secure

${ }^{4}$ http://boldnebraska.org/lawsuit/ Kleeb, Jane, Citizen Lawsuit Challenging Nebraska Unconstitutional Pipeline Process, Jan. 13, 2013,

${ }^{5}$ Thompson v. Heineman, 857 N.W.2d 731 (2015).

${ }^{6}$ Kathleen Miller, The Fifth Judge: Thompson v. Heineman and Nebraska's Judicial Supermajority Clause, 6 Neb. L. Rev. Bull. 1 (2015).

${ }^{7} \mathrm{http}$ //www.nps.gov/wica/historyculture/upload/Treaties and Broken Promises, Chap. 5. Pp. 84-132.pdf

${ }^{8}$ http:///www.pri.org., Robert Boos, Native American tribes unite to fight the Keystone pipeline and government 'disrespect', Feb. 19, 2015.

${ }^{9} \mathrm{http}: / / /$ nativeamericannetroots.net, Ojibwa, Denying Indian Nations Legal Representation, Nov. 11, 2011.

${ }^{10} \mathrm{http}$ //www.vice.com/read/native-american-tribes-ready-to-go-to-war-overkeystone-pipeline-1119 
the interests of the United States in the vast territorial domain of the Lakotas, Cheyennes, and Arapahos, Congress passed Senate Resolution 136, a bill that authorized the creation of the Indian Peace Commission. ${ }^{11}$ In the spring of 1868 , a conference was held at Fort Laramie, which resulted in a treaty with the Sioux. The treaty was to bring peace between the whites and the Sioux who agreed to settle within the Black Hills reservation in the Dakota Territory. To this day, ownership of the Black Hills remains the subject of a legal dispute between the U.S. Government and the Sioux. ${ }^{12}$ The Treaty recognized the area where the projected Keystone pipeline is going to traverse as lands belonging to the Sioux tribe.

Now we travel forward 130 years to our time where the U.S. has grown so vast and technology has advanced so much it is consuming more oil than they can produce. Since the oil crisis of 1973, there are those who would argue that the U.S. energy policy has been in crisis mode. ${ }^{13}$ Oil is a particular resource of which the U.S. cannot seem to get enough. As of 2012, the U.S. consumes the most oil products in the world. China, the next country listed in the top 15, consumes almost half that amount. ${ }^{14}$ The latest data released by the U.S. Energy Information Administration on crude oil imports in September of 2014 reports oil imported from Canada at annually 3,129,000 barrels per day. The next largest importer of crude oil to the U.S. is Saudi Arabia at 1,004,000 barrels per day. ${ }^{15}$ The U.S. consumption of oil has increased annually since in $2008-2013$ by $2,442,000$ barrels per day. ${ }^{16}$ The transportation of the oil imported to the sources of refining the oil into its multiple uses arrives by way of oil tankers, rail, and systems of pipelines that are owned by the producers of oil. As the U.S. demand for oil has increased, Canada's petroleum companies look to increase their market share of the profitable energy business. Already the owner of the Keystone pipeline system, TransCanada proposed an extension to their pipeline, which will include access to areas in North Dakota and Oklahoma where oil is also plentiful. The potential for profit is very real. When they began the process to application in 2006 exports reached $\$ 38$ billion and imports amounted to $\$ 23$ billion. ${ }^{17}$

\section{The keystone $\mathrm{XL}$ developer's position}

TransCanada, a Canadian corporation, owns or has interests in $\$ 48$ billion of long-life assets primarily pipelines and power-generation facilities in Canada, the United States and Mexico and is expected to see $\$ 38$ billion in new projects completed by the end of this decade. ${ }^{18}$ TransCanada claims that they are labor and union friendly and this project has significant value for the U.S. They claim that Keystone Pipeline would put up to 9,000 Americans to work in construction jobs building the pipeline. They claim that an additional 7,000 jobs in manufacturing would be created by this $\$ 5.3$-billion project. They claim that the creation of these jobs will in turn create a demand on local goods and increase annual tax revenue for the local government. TransCanada also asserts that U.S. Gulf refineries have signed up for long commercial contracts that will produce needed products that can be shipped overseas instead of using higher priced oil imported

\footnotetext{
${ }^{11} \mathrm{http} / / /$ www.nps.gov/wica/historyculture/upload/Treaties and Broken

Promises, Chap. 5.Pp. 84-132.pdf

${ }^{12}$ Stacey Bredhoff, American Originals, Seattle: The University of Washington Press, 2001], p.56-57

${ }^{13}$ Grossman, Peter (2013). U.S. Energy Policy and the Pursuit of Failure.

Cambridge University Press.p. 416.

${ }^{14}$ http://eia.gov, U.S. Energy Administration/petroleum, Dec.7,2014

${ }^{15}$ Ibid.

${ }^{16} \mathrm{Ibid}$.

${ }^{17} \mathrm{http}: / /$ www.nrcan.gc.ca/energy/fuel-prices/4597, Dec.6,2014

${ }^{18} \mathrm{http}: / /$ keystone-xl.com/home/transcanada-keystone-xl-pipeline-facts
}

from Venezuela and the Middle East. To counter the claims of potential pipeline leaks, and environmental damage TransCanada claims through their website, specifically designed to promote the Keystone Pipeline states 'that it will be one of the safest pipeline ever constructed in the U.S.'.

They are claiming to be utilizing the most advanced technology to 'monitor 20,000 data points on the pipeline's operating conditions'. They claim that the Keystone XL is an environmentally responsible project. ${ }^{19}$ On their website, www.keystone-xl.com, TransCanada sites several climate scientists that agree that that the project will have no detectable climate effect. TransCanada has invested heavily in lobbying Congress members about the benefits of the pipeline. Their selling point is that the pipeline will bring long-term jobs and economic benefits, energy security, and contribute to building the 'good neighbor' community relationships between the U.S. and Canada. TransCanada remains committed to growth throughout North America. In 2016 they purchased the Columbia Pipeline Group for $\$ 13$ billion. "Columbia Pipeline Group (CPG) owns and operates more than 15,000 miles of strategically located interstate pipeline, gathering and processing assets extending from New York to the Gulf of Mexico, integrated with one of the largest underground natural gas storage systems in North America". ${ }^{20}$ With this acquisition, TransCanada now merges a major puzzle piece for the Canadian corporation and operations in the U.S. ${ }^{21}$ Not dissuaded by the current halt in the Keystone Pipeline expansion "TransCanada continues to review its options and remains committed to building the Keystone XLPipeline ${ }^{22}$ ",

\section{The U.S government position}

U.S. regulations and rules heavily govern a foreign company access to crossing the border to transport oil. Permitting is a bureaucratic process that goes through the US Department of State. 'The Department of State's work in national security, bilateral and multilateral diplomacy, commercial advocacy, environment and development are widely affected by energy concerns. ${ }^{23}$ Responding to the demand to increase alternative sources of access to oil, on April 30, 2004, President George Bush signed into effect Executive Order $1337 .{ }^{24}$ This executive action allowed the President, himself, to 'expedite the review permits to accelerate the completion of energy production and transmission projects... of certain border crossings for land transportation... of facilities connecting the United States with a foreign country, while maintaining safety, public health, and environmental protections... ${ }^{25}$ The President claimed the authority of the Constitution ${ }^{26}$ to 'further the policy' of his administration. His policy, was to demand an imperative on government agencies connected with the permitting process to work to get projects online as quickly as possible. It was promoted as a matter of public necessity. Order 1337 amended the previous order to take the permitting decision directly to the President. Bush's goal was to push through 'good projects' and expedite their completion. In direct opposition to the goal of increasing U.S. need and use of more energy is the issue of climate change. The 2005 Task Force on Confronting Climate Change stated that:

\footnotetext{
${ }^{19} \mathrm{http}: / /$ www.keystonepipeline.com, Jan. 21, 2017.

${ }^{20} \mathrm{https}$ ://www.cpg.com/about-us, Jan. 21, 2017.

${ }^{21} \mathrm{http}: / /$ blog.transcanada.com/columbia-deal-a-game-changer/

${ }^{22} \mathrm{http}: / /$ www.keystonepipeline.com, Jan. 21, 2017.

${ }^{23} \mathrm{http}: / / w w w . s t a t e . g o v / \mathrm{e} / \mathrm{enr} / \mathrm{index} . \mathrm{htm}$

${ }^{24}$ Exec. Order No. 1337, 3 C.F.R.(2004). Print.

${ }^{25}$ Ibid.

${ }^{26} \mathrm{Ibid}$.
} 
The Task Force urges policymakers to not ignore the important economic challenges involved in reducing emissions, noting that nearterm costs "matter because they affect the livelihood of Americans." It argues, though, that a "properly designed and executed domestic policy... can avoid unacceptable shocks or disruptions and smooth the transition to a low-carbon economy.' It also says that climate policy 'presents opportunities to strengthen important parts of the economy and create jobs, to rebuild U.S. partnerships and alliances, and to bolster energy security. ${ }^{27}$ In 2008 TransCanada Corp. applied to the U.S. State Department for a presidential permit to begin construction and to cross the U.S. border with the Keystone Pipeline XL. In 2011 after the department issued its final impact statement for the project. It found no 'significant adverse effects on the environment' and began a comment period to determine if the project 'is in the U.S. national interest' ${ }^{28}$ Later in 2011, after much opposition during the comment period from environmental groups, the assessment for alternative routes to avoid the Sandhills region of Nebraska began. The Sandhills region and the Sioux Nation lands are cross over the Ogallala aquifer in Nebraska. These are public drinking water, and would be particularly vulnerable to leaks from the pipeline.

Strong opposition to the pipeline comes from groups like the Friends of the Earth environmental group and 365.org. They claim that the Keystone XL will 'carry one of the world's dirtiest fuels: tar sands oil. Along its route from Alberta to Texas, this pipeline could devastate ecosystems, pollute water sources and jeopardize public health. They also claim that the tar sand oil, oil that is extracted from sand, produced in these Canadian oil fields will increase carbon emission which have an impact on the climate change. In contrast to the policies of the Bush administration that allowed for the expedited permitting process for oil projects, the focus of the current administration is on renewable energy sources, which has decreased the American need for foreign oil. ${ }^{29}$ Obama's policies move away from focusing on the need for oil, particularly dependence on foreign oil, which Obama sees as a threat to national security. The need for oil project fast-track to operation is no longer part of government policy. Climate change is seen as the greater threat to America's economy and national security. ${ }^{30}$ This set the stage for a shift away for support for the Keystone Pipeline expansion.

This shift in policy has been met with opposition by many in Congress that submit several bills to force the President to sign the permit and let the project go forward. ${ }^{31}$ They argue that pipeline is in the public interest because of the forecast for jobs and revenue, but critics say the truth is that the pipeline is a really just a money maker for those who are heavily invested in it. ${ }^{32}$ The same executive power that allowed President Bush to push the project forward, was the act that President Obama used to stop the project going forward. The environmental lobbies took the Keystone XL expansion as an opportunity to advance

\footnotetext{
${ }^{27}$ Rubenstein, David M., The Task Force, and Confronting Climate Change: A Strategy for U.S. Foreign Policy, directed by Senior Fellow for Energy and Environment Michael A. Levi and advised by Adjunct Senior Fellow David G. Victor.

${ }^{28} \mathrm{http}: / /$ www.reuters.com/Scott Haggett, Timeline: The six-year battle over the Keystone XL /article/2014/11/13/

${ }^{29} \mathrm{http} / / / \mathrm{www}$.whitehouse.gov/energy/securing-american-energy. Access 9/18/2016.

${ }^{30} \mathrm{Ibid}$.

${ }^{31}$ Christopher Sands, What Did Congress Accomplish with the Keystone Vote?,http:///thehill.com, 2/25/2015.

${ }^{32}$ Tina Casey, The Transportation Game: Keystone XL Pipeline, \& Why The Koch Brothers Can’t Let Go, http://www.cleantechnica.com, 2/10/2015.
}

their position against fossil fuel development. ${ }^{33}$ Canadian America Tribes, involved with the indigenous climate campaign and anti- tar sands knew the damage that tar sand oil extraction and transportation caused to their land. ${ }^{34}$ They reached out to tribal councils in the U.S. to help coordinate the effort to get their message to President Obama at the tribal leaders' summits. Through the representative of Rosebud [Sioux tribe], the area of the projected pipeline, the Native American communities gave Obama a declaration opposing Keystone XL. ${ }^{35}$ The declaration had thousands of signatures. On November 15, 2015, President Obama vetoed Congress' attempt to legislate the building of the pipeline. In a highly publicize and politically charged action, Obama vetoed S.1 Keystone Pipe Line Approval Act. He declared that "after extensive public outreach and consultation with other Cabinet agencies, the State Department has decided that the Keystone XL Pipeline would not serve the national interest of the United States." 36 Heavily invested in the upcoming climate change summit in Paris that began in three weeks, the President discussed at length that he did not see any benefit to the U.S. economy or the global environment of the pipeline being built. There was no mention of the land use dispute between TransCanada, American property owners, or the Native American tribes. ${ }^{37}$

There is much discussion whether the new Trump administration will go forward with permitting the expansion of the Keystone Pipeline. ${ }^{38}$ Interestingly, now that Obama is out of office, the truth that State Department figures that "Keystone XL's promise to invest $\$ 8$ billion to create 42,100 man-years of work" are viewed as figures representing short term construction jobs. ${ }^{39}$ The permitting process may become more complicated because Trump, who has focused on countries not paying their fair share of defense protection, may request that a new application for the pipeline be submitted since the original permit application was dated in $2012 .{ }^{40}$ This will further stall the pipeline going forward. This political jockeying still does not involve recognizing or discussing the sovereignty of the local tribes over their protected lands.

\section{Conflicting political positions}

Regular protests in Washington brought attention to the Keystone Pipeline issue. The private citizen land rights owners and the Native American tribal representatives marched on the Capital. 'The theme of the week was "Cowboys and Indians" a tongue-in-cheek reference to classic, if politically incorrect, westerns and kids' games of shoot'emup. The two groups stand united in opposition to the pipeline; in coming to DC, they hoped to make President Obama and the US Department of State aware that the project could have devastating effects on the lives and livelihoods of all who were present. ${ }^{41}$ When it comes to the Keystone XL pipeline, some people claimed that there is

${ }^{33}$ Ben Adler, The Inside Story of How the Keystone Fight Was Won, http:/// newsweek.com, 11/10/2015.

${ }^{34}$ Ibid.

${ }^{35} \mathrm{Ibid}$.

${ }^{36}$ Statement by the President on the Keystone XL Pipeline, http://whitehouse. gov, $11 / 6 / 2015$.

${ }^{37}$ Ibid.

${ }^{38}$ Danny Lam and Maurice Dusseault, Trump Unlikely to Approve Keystone XL Quickly, http://thehill.com/blogs/pundits-blog/energy-environment, Jan. 09,2017

${ }^{39}$ Ibid.

${ }^{40} \mathrm{John}$ Paul Tasker,A Trump presidency could add pressure on Canada's defense spending. http://www.cbc.ca/news/politics.Jan. 21, 2017.

${ }^{41}$ http://billmoyers.com, Native Americans Ranchers Take to National Mall to Protest-Keystone Pipeline, 4/20/2014. 
an element of tribal politics in the opposition. Native American Tribes are looking for causes to get involved in to change public awareness of the needs of their people. During the 2008 campaign, the Crow received attention for making Obama an honorary member, bestowing him with the name 'One Who Helps People throughout the Land.' In an article published in the American Indian Law Journal, Mary Christina Woods writes, 'Statutory law, passed with the interests of the majority society in mind, typically ignores unique tribal concerns. But even apart from that, statutory law has become dysfunctional in its own right, no longer carried out to benefit even the majority society. The protection it once offered has withered as a result of relentless political pressure mounted by industry and private interests seeking to influence agency decisions. ${ }^{42}$

In the article, she discusses Indian trust doctrine and Public trust doctrine. 'While Congress and state legislatures passed statutes to prevent further damage to the environment, nearly all of them have provisions allowing the agencies to permit some amount of damage. These permit provisions were never supposed to subvert the statutes' protective purposes, but that is in fact what has happened.' Nebraska Governor Heineman, a pro pipeline activist, moved to subvert the President's stalling on approval of a permit with a revised route for the Keystone XL pipeline that would link Canadian oil sands to refineries in Texas, adding pressure on the Obama administration to give the goahead to the controversial project. ${ }^{43}$ In the House of Representatives, Congress passed Bill S.582 - 113th Congress (2013-2014). The bill did not pass the Senate. The new Republican dominant Congress took up the bill in early 2015. This bill was almost in complete opposition to the Executive order of Republican President George Bush. It returns the permitting approval to Congress, out of the hands of the Executive Branch, and limits the judicial review.

In summary, Bill S.582: Authorizes TransCanada Keystone Pipeline, L.P. to construct, connect, operate, and maintain pipeline facilities for the import of crude oil and other hydrocarbons at the United States-Canada Border at Phillips County, Montana, in accordance with a certain application filed with the Department of State on May 4, 2012 declares that no Executive Order, provision of law, or presidential permit shall be required for such facilities. Deems a certain Environmental Impact Statement issued by the Secretary of State and other specified documents to satisfy all requirements of the National Environmental Policy Act of 1969 (NEPA), as well as any other law requiring federal agency consultation or review regarding such cross-border facilities. Keeps in effect any federal permit or authorization issued before the enactment of this Act for the facilities described in this Act and for related facilities in the United States. Restricts to the U.S. Court of Appeals for the District of Columbia Circuit any federal judicial review over actions and facilities implemented under this Act. ${ }^{44}$ The U.S. State Department suspended its review of the project pending the outcome of the Nebraska appeal. President Obama made it clear that he was not going to support Pipeline. What is most significant about this bill, would be the reversal of the need for a Presidential participation in the permitting process. The effect of this veto is precarious as the November 2016 elections will bring a change in the political leadership. Just as there was a policy change away from support of the pipeline development after Bush, a

${ }^{42}$ Christina Wood, Nature's Trust: Environmental Law for a New Ecological Age, http://www.foe.org/projects/climate-and-energy/tar-sands/keystone-xlpipeline/Maryat 3-120 (Part I). (2013).

${ }^{43}$ http://www.foxbusiness.com/markets, Nebraska Oks Revised Keystone XL Plan. 1/22/2013

${ }^{44}$ To approve the Keystone XL Pipeline. S.582 PCS, $113^{\text {th }}$ Cong. $§ 1(2013-$ 2014). new president could sway the pendulum back to the argument that climate change is a hoax and that national security and the economy requires the continued advancement of fossil fuel development.

\section{The Native American position}

'The Bureau of Indian Affairs in the Interior Department has acted as Indians' trustee for resources on the Native American lands, though Native Americans have complained that it has often done a poor job of guarding their interests'. ${ }^{45}$ For the Native Americans in opposition, the fight is over the land to which they belong. Cushing, Oklahoma along which the southern path of the Keystone Pipeline passes 'sits in the Sac and Fox Nation, part of a patchwork of land belonging to Oklahoma's 38 tribes, each with sovereignty over its own affairs and land....TransCanada's plan to dig a trench and bury part of its $\$ 7$ billion, 1,700-mile Keystone XL pipeline right through this land has unearthed a host of Native American opposition, resentments and ghosts of the past. ${ }^{46}$ American tribes argue that through the $19^{\text {th }}$ century treaties, whether or not they have been honored since that time, they are affirmed sovereign status and that they have their own governing councils. Despite being provided this status by the Treaties, Jennifer Baker, a Colorado-based lawyer who has worked closely with South Dakota tribes states an obstacle to recognition of the tribes is because 'history has developed so that legal truths get overshadowed by factual realities, and judges tend to mold the law to reflect factual realities. ${ }^{47}$

The Iowa Nation chairman stated, 'All we're asking for is respect, respect for us as a people...'Above all the land is sacred, it's not just a mantra. People really do see this as sacred land. It really causes a lot of people a lot of pain, particularly the elders. They recognize the damage this has the potential for ${ }^{48}$ Cyril Scott, Chief of the Rosebud Lakota Tribe was quoted saying, 'Because the lands the Pipeline will cross are Sacred Treaty Lands and to violate these lands by digging ditches for the pipelines is blasphemes to the beliefs of the Native Americans. Violating the human and religious rights of a people in order to create jobs and low cost fuel is the worst form of capitalism. ${ }^{49}$

\section{An analysis of the legal topics involved:TransCanada's battle in state and federal court}

The Nebraska Supreme Court overturned a lower court's ruling that the law allowing the pipeline expansion was unconstitutional..$^{50}$ April 17, 2012, Nebraska legislative Bill 1161 went up for a vote. Eager to be a part of the promised revenue windfall from the Keystone Pipeline, and in order to pressure President Obama to sign the permit, the Nebraska legislature passed, law $L B 1161$ which 'confers upon the Governor, instead of the Public Service Commission (PSC), power to authorize pipeline common carriers to do business in Nebraska. The law allows the State to pay cost credits on behalf of the pipeline for feasibility studies, etc. Three Nebraska private citizens filed a lawsuit, Thompson v. Heineman, challenging the constitutional basis of $L B 1161$, Nebraska's current pipeline routing law. The lawsuit claimed that by taking the power from the PSC

${ }^{45}$ Exec. Order No. 13211 C.F.R. 770 (2001).

${ }^{46}$ Steven Mufson, Keystone XL Pipeline Raises TribalConcerns,http://www. washingtonpost.com/business/economy//September 17, 2012.

${ }^{47}$ Wood, Mary Christina Wood, Tribal Environmental Leaders Summit Keynote. Address, Tribal Trustees in Climate Crisis, American Indian Law Journal, Volume II, Issue II, Spring 2014, at 3

${ }^{48}$ Ibid. at 6.

${ }^{49}$ Tim Giago, The Final Indian War About to Begin, http://www.huffingtonpost. com, $11 / 16 / 2014$

${ }^{50}$ Thompson v. Heineman, S-14-000158, Nebraska Supreme Court (Lincoln). 
which state constitutional has authority over pipelines, and instead giving the authority to the Governor. The lawsuit also claimed that $L B$ 1161 violates the separation of powers because it fails to provide for judicial review. The plaintiffs argued that the law unlawfully delegates to the governor the decision to permit exercise of the eminent domain without 'adequate and definite standards required for constitutional due process'. In this situation, TransCanada, a foreign corporation, would be awarded the power of eminent domain before they have all their permits in place.

In her decision, Judge Stacy rejected Nebraska's argument that the landowners, taxpayers, did not have the right to sue. Nebraska argued that TransCanada reimbursed the state more than $\$ 5.15$ million. This reimbursement countered the claim the people had not been harmed. In her remarks she said, 'While private reimbursement of public expenditures may be good fiscal policy, it should not be used as a legislative tool to insulate allegedly unconstitutional laws from taxpayer challenge'. The ruling includes a permanent injunction preventing Gov. Dave Heineman, and the Nebraska Department of Environmental Quality from taking any further action to authorize or advance the pipeline under the unconstitutional law. The State of Nebraska appealed. On appeal the State claimed that, 'The district court erred in

i. Determining Appellees had standing as taxpayers to bring their claims;

ii. Determining an environmental review of a proposed pipeline route conducted by Nebraska Department of Environmental Quality and subsequently approved by the Governor for oil pipelines that are not intrastate common carriers divests the Public Service Commission of authority in violation of Neb. Const. art. IV, § 20;

\section{iii. Considering evidence, E32, not admitted to the record. ${ }^{51}$}

The decision of the lower court was affirmed, and the Plaintiff took their case to the Supreme Court of Nebraska. Oral arguments were heard on September 5, 2014..$^{52}$ On Jan. 9, 2015, the Supreme Court overturned the lower court's ruling not on the merits of the case but on a procedural technicality. 'Four out of the seven Nebraska Supreme Court judges concluded that the law was unconstitutional, but the Nebraska Constitution requires a supermajority of five judges to weigh the opinion of the court. Some of the seven-judge panel chose not to participate in the vote, leaving the court deadlocked.' Lawyers for the plaintiff claim this as a non-decision open to further review. The legislation must stand by default.After the Nebraska court's decision, revitalized, TransCanada lobbied Congress heavily to support the pipeline expansion, but President Obama's veto of Congress' Keystone Pipeline XL bill. In January of 2016, TransCanada LP through their Houston based subsidiary, TC Oil Pipeline Operations Inc., filed a Constitutional claim in the Southern District Federal Court..$^{53}$ The Plaintiff's claim that the President's veto was a unilateral act, politically motivated by Obama's desire to have greater influence in international affairs concerning the Paris climate change negotiations. The complaint states that the President unconstitutionally over stepped his authority in regulating commerce because the cross-border pipeline crossing issue is incidental to

\footnotetext{
${ }^{51}$ Randy Thompson, Susan Straka, f/n/a Susan Luebbe, Susan Dunavan v. Dave Heineman, S-14-0158, Nebraska Supreme Court (Lincoln)

${ }^{52} \mathrm{http}$ //Omaha.com, Joe Duggan / World-Herald Bureau, In 30-minute hearing, Nebraska Supreme Court fires 55 questions at lawyers in Keystone XL pipeline case, September 6, 2014

${ }^{53}$ Complaint, TransCanada Keystone Pipeline, LP et al v. Kerry et al, No. 4:2016cv00036, S.D. Tex. (Jan. 2016).
}

the public interest of potential jobs and furthering good relations with Canada. TransCanada claims that "Article I, Section 8 of the Constitution provides for Congress "[t]o regulate Commerce with foreign Nations, and among the several States." The Constitution thus provides Congress with the express power to authorize, regulate, or prohibit the development of commercial transportation facilities such as the Keystone XL Pipeline, which crosses both international and interstate borders ${ }^{54}$ ". TransCanada claims that the President acted in opposition to Congress's express powers. They are seeking injunctive relief from the President exercising, what they argue, is a veto without any authority. ${ }^{55}$

This law suit is just beginning to make its way through the federal courts. Political appointees of former president Obama, are the named defendants in this law suit. As the request for relief moves through the court, the complaint needs to be amended to include the names of executive appointees of the incoming President Trump indicated during his campaign that he may be interested in getting the Keystone XL pipeline going again as part of the rollback of former President Obama's climate change policies. ${ }^{56}$ Trump, however, may be in less of a hurry to "expedite approval of a quasi-foreign project that appears to lack significant American benefits". ${ }^{57}$ Trump, unlike Congress, may be willing to acknowledge that Keystone Pipeline XL provides windfall profits to the Canadian corporation with few jobs or revenue realized by the U.S. The purpose of this paper is not to analyze TransCanada's legal and political battle to get permitting for their pipeline. It is not only to emphasize the complexity of the issues, but to make evident that key stakeholders are absent from the process: the Native American Tribes.

\section{The tribal argument}

Absent from any legal filings are issues involving the Native American sovereignty over lands that the pipeline will cross. When Lakota Chief Scott spoke about going to war with those who would invade their land with the pipeline, he clarified that by saying that he was not speaking metaphorically or figuratively. "If they come to our land, that's what I mean," he said. "If it comes down to it. We hope it don't, we'd rather use a legal war." The Fort Laramie treaties ceded all of South Dakota west of the Missouri River to the Lakota tribes, or Sioux. While legislation has reduced the size of that reservation, the treaties were never revoked. Attorney Baker says they should still be considered in force. 'Even under congressional legislation, a process of consultation is required for all federal agencies.' However, the State Department, which is weighing the Keystone XL cross-border permit, told tribes that their concerns belonged in the open meetings forums with other citizens. They were not consulted with the status of a sovereign nation.

'Invoking their sovereign status, tribes have creatively used all sorts of arrangements and legal footholds to re-position themselves as active co-trustees across ceded territory. The various approaches include treaty rights litigation.' In Canada there is a duty to consult 'based on the honor of the crown' when there is knowledge of Aboriginal rights that are established by treaty. ${ }^{58}$ The Supreme Court of Canada ruled that mutual agreements need to be reasonable. 'A

\section{${ }^{54}$ Ibid. at 26 \\ ${ }^{55}$ Ibdd.at 48 .}

${ }^{56} \mathrm{http}: / / w w w . w a s h i n g t o n e x a m i n e r . c o m / t r u m p-l o o k s-t o-s p e e d-u p-k e y s t o n e-x l-$ with-executive-actions/article/2612458, Jan. 21, 2017.

${ }^{57}$ http://thehill.com/blogs/pundits-blog/energy-environment/313400-trumpunlikely-to-approve-keystone-xl-quickly. Jan. 21, 2017.

${ }^{58} \mathrm{http}$ //www.newsweek.com/Why Nebraska Supreme Court Decision Might Be Bad News Keystone XL, 1/09/2015. 31Mikisew Cree First Nation v Canada (Minister of Canadian Heritage), 2005 SCC 69, 3 SCR 388 at 47-48. 
key factor to be considered in assessing the reasonableness of a decision... is an effort to reach mutual agreement.' At this point, none of the Native American tribes have been reached out to for legally binding discussion, as TransCanada has stated that they have no obligation to that discussion. TransCanada's position has been: 'There is no legal obligation to work with the tribes,' said Lou Thompson, TransCanada's top liaison with Native Americans. "We do it because we have a policy. We believe it's a good, neighborly thing to do." He said the pipeline 'is not passing through any tribal lands. ${ }^{59}$ ' The Native American tribes had yet to challenge the Keystone Pipeline $\mathrm{XL}$ expansion in court, there was only a promise to go to court if the President issued the permit. The decision in the Nevada case is significant because it left open the discussion of state statutes that provide the taking of land in order to build pipelines by the foreign corporation. Again, if the Nevada Supreme Court decides to reverse the decision of the appellate court, and the Nebraska law allowing the permit to be issued by the Governor is reinstated, the Lakota has vowed to fight in court.

\section{Conclusion}

In writing on environmental law and Native American Tribal rights, Christina Woods states: Environmental law has failed its basic purpose of protecting the planet's resources. Its continued legalization of damage through the permitting process now brings unthinkable threats to future civilization. Yet the legal system still pushes the same disastrous course that has brought us to this point. Global multinational corporations still gain free license under existing environmental law to cause irreparable harm to our planet's atmosphere and other life systems. For example, development of Canadian tar sands finds fervent political support among U.S. and Canadian governmental officials - even though, in the words of a leading climate scientist, the resulting carbon emissions would amount to "game over for the climate." Citizens should recognize something deeply, and terrifyingly, wrong with their government. It is speculated that this Canadian based corporation spent upwards of 11 million dollars lobbying for the expansion of an oil pipeline. Whatever they spent, they did not make this investment because they are concerned with the economy of the U.S. The facts show that the U.S. no longer has the same reliance on foreign oil.

The major benefactors of a project such as this clearly belongs to the owner of the oil, the builder of the pipeline and their investors. By permitting the Keystone Pipeline expansion, the U.S. government opens the American people to deeper dependence on foreign interests. Many, even possibly the new president are willing to admit that the Keystone Pipeline XL extension's sole benefit is to advance the financial gain of TransCanada. With this fact in mind, what policy or pubic interest is served such that state leaders, the President, the Congress, and the Judiciary system surrender to the manipulation of TransCanada? What is in it for them? The fight for the Keystone XL pipeline extension continues. In addition to TransCanada's filing in January, in June of 2016, they filed under Chapter 11 of the National Free Trade Agreement requesting arbitration seeking relief in the amount of $\$ 15$ billion dollars. ${ }^{60}$ With a new administration in

\footnotetext{
${ }^{59} \mathrm{http}: / /$ www.keystone-XL.com

${ }^{60} \mathrm{http}: / / \mathrm{www}$. keystone-xl.com/wp-content, TransCanada Request for Arbitration. 6/2016.
}

place that is favorable to oil and gas development "new paths in the jurisprudence of international agreements." will likely be forged. ${ }^{61}$ The Nebraska Supreme Court ruling that allowed the Governor to grant a permit taking private landowners rights away, by default, still stands. Arguably, the lower court's ruling is an unconstitutional use of power. The ruling allowed Governor Heineman to supplant the land rights of private citizens. Because of a technicality, the Nebraska Supreme Court was unable to affirm this position. With TransCanada purchasing a U.S. based pipeline company, the issue of crossing the border becomes less of the obstacle to pipelines crossing over environmentally sensitive lands and aquifers.

The rightful sovereignty of the Native American people's as protectors of the land, if allowed to be heard in court, we believe, may be the trump card in what appears to be a web of political and legal manipulation for the benefit of the TransCanada Corporation and big oil investors. Per the Treaties, nothing can happen on those lands without their consent. U.S. Secretary of the Interior Sally Jewell, speaking for the Obama Administration, invoked not only tribal sovereignty but also environmental expertise when she spoke about the Keystone XL pipeline, "I think the fact that the tribal nations are standing up saying, 'We are concerned about this. We are concerned about water quality. We're concerned about tribal sovereignty. We're concerned about what this pipeline may do for our lands and our rights," needs to be heard..$^{62}$ It is unsure what direction the new administration will take. In 2015President Obama rejected the Keystone XL. ${ }^{63}$ There was no mention then of the Native American sovereignty rights, but there is now notice by the government of these rights. On September 9, 2016, the former Administration reaffirmed its stance on protecting the environment, but this time in direct response to massive protests by multiple Native American tribes over the Dakota Access Pipeline, the Obama administration halted work on a $\$ 3.7$ billion oil pipeline in North Dakota. Many activists proclaimed this project the virtual sister of Keystone XL. ${ }^{64}$ Even if the Trump administration decides to allow the permit, the Native Americans must be ready to exercise their legal rights under the Treaties of Laramie. They can challenge any permits that may be granted. History shows that they cannot rely on support from the U.S. government. The more money is involved, the more politically divisive the issue. Public opinion is recognizing Native American people. Time will tell how these thorny matters will play out in the courts and our country. The environment is important to all of us, and Native American sovereignty may be our only protector.

\section{Acknowledgments}

None.

\section{Conflicts of interest}

The author declares there are no conflicts of interest.

\footnotetext{
${ }^{61}$ Ayesha Rascoe, TransCanada legal challenges over Keystone pipeline face long odds,

${ }^{62}$ Sally Jewel, They know their lands better than we do. http://www.tulalipnews. com/on-tribal-keystone-xl-opposition. 12/08/2014.

${ }^{63}$ Labott and Berman.Obama Rejects Keystone XL Pipeline, CNN, http://www. cnn.com, November 6, 2015.

${ }^{64}$ ElanaSchor. Obama halts new pipeline that protesters see as Keystone sequel, http://www.politico.com/story9/9/16.
} 